\title{
Industrial and Non-Industrial Medicine - The Power of Money vs. the Power of Personal Contact and Empathy
}

\author{
Søren Ventegodt \\ Quality of Life Research Center, Research Clinic for Holistic Medicine, Nordic School of Holistic Medicine, Denmark
}

"Corresponding author: Søren Ventegodt, Quality of Life Research Center, Research Clinic for Holistic Medicine, Nordic School of Holistic Medicine, Frederiksberg Alle 13A, 2.t.v, 1621 København V, Denmark, Tel: +453314 11 13/+45 206667 66; E-mail: ventegodt@qualityoflife.dk, ventegodt@livskvalitet.org

Rec date: Apr 11 2014; Acc date: Apr 15 2014; Pub date: Apr 172014

Copyright: ( 2014 Ventegodt S. This is an open-access article distributed under the terms of the Creative Commons Attribution License, which permits unrestricted use, distribution, and reproduction in any medium, provided the original author and source are credited.

\section{Psychosomatic medicine}

So many wonderful and horrible things are happening in medicine these days. The good, old medicine, where the doctor himself, his empathy and wisdom, is the tool is again main stream [1].

Psychosomatic medicine, CAM, alternative medicine, holistic medicine, you name it - is basically the old classical medicine using nothing but a shift in the patients' consciousness, caused by understanding or trust - often called the "placebo effect". In rigid scientific studies this medicine has now been proven able to cure even the most serious physical diseases. It works wonders with coronary heart disease and even cancer, [2-6] as we saw it with David Spiegel et al. [6] and Dean Ornish et al. [2] great papers during the last decades.

Psychotherapy has been found extremely effective for almost all mental and psychiatric disorders - often 19 out of 20 patients have been cured, and without significant side effects, as recent meta analyses by Leischenring et al. have shown [7-10].

Isn't that wonderful? We now have cheap and effective, evidencebased medicine completely without side effects - without all the horrible adverse effects always associated with the use of drugs! - that can heal almost all diseases known to man, if the patient just understands to cooperate with the treatment? What a great achievement for mankind.

And on the other side, we have the horror of our time: the massive manipulation of the academic institutions and of national and international health organizations worldwide, including the WHO, by the pharmaceutical industry, making billions of people believe in the effectivity of drugs and vaccination programs etc. without any scientifically documented significant beneficial effect, but with countless serious adverse effects, leading to the death of hundreds of thousands of patients according to the leader of the Nordic Cochrane Center, Peter Gøtzsche. He recently documented this in a number of articles in Danish media [11] and a much debated book with the dramatic tittle "Deadly Medicines and Organised Crime: How Big Pharma Has Corrupted Healthcare" [12]. Honestly you would not expect an established and honored professor at the University Hospital write such a book; you need to read it yourself to understand that the tittle is actually an accurate summery of what is well documented in the book. This is an important book and a must-read for all leaders and politicians in healthcare.

In articles in the major Danish newspaper Politiken professor Gøtzsche has estimated that about 3500 Danish citizens every year die of adverse effects of medicine [13] - dangerous and ineffective drugs they most often should not have had to begin with [12].
These two opposite trends in medicine - industrial pharmaceutical drugs and vaccines on one side, and the old-school traditional one-toone encounter aimed for problem solving and understanding - are often clashing.

Patients are getting confused and researchers in holistic medicine are often framed and attacked by people and organizations close to the pharmaceutical industry, as Gøtzsche also documented in his books, where you can read that some companies even have hit-list for the researchers who research in the adverse effects of their products!

My close colleagues in holistic medicine research and I have even met researchers who told us that big companies have been threatened to end their lives if they continued to document that the companies' drugs and vaccines are without beneficial effects [14].

And many more researchers have been scandalized by falls accusation of violent and sexual abuse of patients etc, most often presented in the boulevard press by psychiatrist who are totally dependent of the use of the psychopharmacological drugs which Peter Gøtzsche and other Cochrane researchers have found should be taken of the market [11].

What we need to do is to make it clear to the people and politicians of our countries that we now have two conflicting trends in medicine: one build on appreciation of the power of personal contact with the patient and driven by good hearts; and another build on the believe in the magical bullet and driven by big money.

The first is based on empathy, the patients understanding of own disease- and recovery process, and a celebration of the healing forces in each individual, to be called upon in case of disease using concepts and exercises related to feelings, emotional intelligence, intuition, love, fulfillment of deep existential needs, understanding, self-realization, and the healing power of freeing ones sexuality. In Denmark we often can call this classical holistic approach to healing for "love as medicine" [15-20].

The other is based on the big money in the pharmaceutical industry. Power and money are, as Gøtzsche have shown us, changing truth into untruth and the untrue into public truth and believes.

Drugs which are extremely dangerous and poisonous, even deadly, are sold as safe and good medicine, and even recommended by authorities and doctors with close relations to the industry, in spite of the existence of cheaper, much safer and thousand times more effective alternatives.

In these troubled days in medicine it is important that we make it clear for ourselves where we stand. 
Page 2 of 2

I feel that most doctors involved in alternative medicine hold on to classical values like respect for the patient and his autonomy, personal integrity and honesty. The understanding that our patients are greatly helped when we let these values guide our actions and choices is what originally led to the concept of medical ethics [21].

Science must be sound and unbiased. Nothing is as easily manipulated as measuring and documentation of positive and negative effects, as Gøtzsche has shown us in his book [12] and in his many papers and even a doctoral thesis on this subject.

Basically an objective measurement cannot be done by anyone with an interest. The pharmaceutical industry cannot test its own products, and the state cannot manage medicine, as it is too susceptible to the influence of big money.

This means that the scientific medicine is in severe trouble. The problems are so important and severe that even the results from the medical science cannot be trusted anymore, as Gøtzsche has explained us [11-13].

The only solution I see is to set medicine free.

The state must do everything it can to stop the suppression of alternative medicine. To support the doctors practicing alternative medicine, every doctor must be allowed to treat according to his or her own believe, understanding and knowledge. And the patients must have the right to choose a doctor that matches his or her understanding and believe of life and medicine.

Drugs should be tested by independent organizations with no relationship to the industry, the academic institutions or to the state.

All means that can stop the pharmaceutical industry from dominating and manipulating people, organizations and society at large must be taking into use. Commercials for drugs must be banned or only allowed if the NNT-numbers (often showing that only one patient in [20] or so is helped by the drugs [22]), the adverse effects (often dozens) and the NNH-numbers (showing that most patients are harmed by most drugs) are also listed in the commercial. If people only knew the truth about the drugs, or just what can be learned from the major independent Cochrane reviews, they would not take them.

The most reasonable thing to do in this situation is as radical as Gøtzsches book: All pharmaceutical industry payment to doctors who are involved in the treatment of patients must be forbidden. Testing of medicine must me a job for independent organizations paid by the state, but not controlled by the state. Public tender is one way to do it. But there are many other good solutions, of course.

With political will it is not impossible to realize the ideas of keeping medicine healthy even in a money-driven and "practical" world.

At least we must try.

If we are not fighting for medicine know, we risk to loose thousands of years of collected wisdom in medicine; we risk lose the blessed tradition of good doctors and therapists healing and helping the weak and diseased.

\section{Let's not do that.}

Let's not loose what is priceless and impossible to replace.

With half of the population ill in most western countries we more than ever need the great medicine where consciousness is in focus and the "doctor is the tool".

\section{References}

1. Chopra D, Ornish D, Roy R, Weil A (2009)Alternative' Medicine Is Mainstream. The evidence is mounting that diet and lifestyle are the best cures for our worst afflictions. Wall Street Journal.

2. Ornish D, Brown SE, Scherwitz LW, Billings JH, Armstrong WT, et al. (1990) Can lifestyle changes reverse coronary heart disease? The Lifestyle Heart Trial. Lancet 336: 129-133.

3. Ornish D, Scherwitz LW, Billings JH, Brown SE, Gould KL, et al. (1998) Intensive lifestyle changes for reversal of coronary heart disease. JAMA 280: 2001-2007.

4. Ornish ${ }^{\mathrm{D}}$ (1998) Avoiding revascularization with lifestyle changes: The Multicenter Lifestyle Demonstration Project. Am J Cardiol 82: $72 \mathrm{~T}-76 \mathrm{~T}$.

5. Frattaroli $\mathrm{I}$, Weidner G, Dnistrian AM, Kemp C, Daubenmier JJ, et al. (2008) Clinical events in prostate cancer lifestyle trial: results from two years of follow-up. Urology 72: 1319-1323.

6. Spiegel D, Bloom JR, Kraemer HC, Gottheil E (1989) Effect of psychosocial treatment on survival of patients with metastatic breast cancer. Lancet 2: 888-891.

7. Leichsenring F, Rabung S, Leibing E (2004) The efficacy of short-term psychodynamic psychotherapy in specific psychiatric disorders: a meta-analysis. Arch Gen Psychiatry 61: 1208-1216.

8. Leichsenring $\mathrm{F}(2005)$ Are psychodynamic and psychoanalytic therapies effective?: A review of empirical data. Int J Psychoanal 86 841-868.

9. Leichsenring F, Leibing E (2007) Psychodynamic psychotherapy: a systematic review of techniques, indications and empirical evidence. Psychol Psychother 80:217-228.

10. Leichsenring F, Rabung S (2008) Effectiveness of long-term psychodynamic psychotherapy: a meta-analysis. JAMA 300: 1551-1565.

11. Gøtzsche PC (2014) Psychiatry has gone astray. We would be far better off if all psychotropic drugs were removed from the market. The doctors are not able to handle them. [Psykiatri på afveje. Vi ville være langt bedre stillet, hvis alle psykofarmaka blev fjernet fra markedet. Lægerne er ikke i stand til at håndtere dem.] Kroniken. Politiken.

12. Gøtzsche P (2013) Deadly Medicines and Organised Crime: How Big Pharma Has Corrupted Healthcare", New York: Radcliffe.

13. Thomsen S (2013) Medicine is responsible for the dead of thousands of citizens each year. Adverse reactions and medication errors are costing numerous lives annually. [Medicin er skyld i tusindvis af døsfald hvert år. Bivirkninger og medicineringsfejl koster mange menneskeliv årligt.] Politiken.

14. Ventegodt S, Andersen NJ, Kandel I (2009) Bio- and alternative medicine in conflict. Human rights protection of the alternative therapist. J Altern Med Res 1: 189-202

15. Ventegodt S, Merrick J (2012) Textbook on Evidence-Based Holistic Mind-Body Medicine: Basic Philosophy and Ethics of Traditional Hippocratic Medicine. New York: Nova Science.

16. Ventegodt S, Merrick J (2012) Textbook on Evidence-Based Holistic Mind-Body Medicine: Basic Principles of Healing in Traditional Hippocratic Medicine. New York: Nova Science.

17. Ventegodt S, Merrick J (2012) Textbook on Evidence-Based Holistic Mind-Body Medicine: Healing the mind in Traditional Hippocratic Medicine. New York: Nova Science.

18. Ventegodt S, Merrick J (2013) Textbook on Evidence-Based Holistic Mind-Body Medicine: Holistic Practice of Traditional Hippocratic Medicine. New York: Nova Science

19. Ventegodt S, Merrick J (2013) Textbook on Evidence-Based Holistic Mind-Body Medicine: Research, Philosophy, Economy and Politics of Traditional Hippocratic Medicine. New York: Nova Science, 2013.

20. Ventegodt S, Merrick J (2013) Textbook on Evidence-Based Holistic Mind-Body Medicine: Sexology and Traditional Hippocratic Medicine. New York: Nova Science, 2013.

21. de Vibe M, Bell E, Merrick J, Omar HA, Ventegodt S (2008) Ethics and holistic healthcare practice. ${ }^{\text {Int }}$ J Child Health Hum Dev 1: 23-28.

22. Smith R (2003) The drugs don't work. BMJ 327. 